We are grateful to Journal of Chemical Research for permission to publish the full paper on line.

\title{
Synthesis and structural aspects of some intermediates in furofuran lignan synthesis
}

\author{
Ana P. Esteves*, Maria A. Lemos, Maria J. Medeiros and Lígia M. Rodrigues \\ Centro de Química, Departamento de Química, Universidade do Minho, Campus de \\ Gualtar, 4710-057 Braga, Portugal
}

The synthesis of some intermediates of furofuran lignans was accomplished by a chemical cyclisation reaction using N-ethylpiperidine hypophosphite and azobisisobutyronitrile. This reaction afforded the 5-exo-dig cyclic compound as the major product along with another isomeric cyclic compound which possess an endocyclic double bond.

A brief discussion is presented to explain the formation of these isomeric cyclic compounds by a base-catalysed tautomerism mechanism. Some structural aspects are discussed based on nuclear magnetic resonance data.

Keywords: radical cyclisation, hypophosphite salt, furofuran lignans

Biologically-active naturally occurring lignans have attracted considerable attention from organic chemists. ${ }^{1}$ Radicalcyclisation continues to be a method for the preparation of natural products containing heterocyclic rings. ${ }^{2,3}$ Most radical cyclisations in heterocyclic chemistry are still accomplished using tri-n-butyltin hydride, Bu3SnH.3-5 Such syntheses involve the use of an excess of $\mathrm{Bu}_{3} \mathrm{SnH}$ in the presence of a small amount of radical initiator, usually azobisisobutyronitrile (AIBN).

To avoid the problems associated with the use of $\mathrm{Bu}_{3} \mathrm{SnH}$, such as, product purification, high cost and toxicity, considerable effort has been aimed at the development of more user- and 
environmentally-friendly reagents for the generation of reactive radicals. ${ }^{6,7}$ For example, $\mathrm{C}-$ $\mathrm{C}$ bond formation by radical cyclisation has been performed using hypophosphite salts (e.g. N-ethylpiperidine hypophosphite, EPHP) acting on alkyl bromide substrates with alkyne ${ }^{8,9}$ or alkene ${ }^{10}$ side chains.

A convenient alternative to synthetic methods involving organometallic hydrides is the use of electrogenerated nickel(I) complexes as mediators for reductive intramolecular cyclisations. ${ }^{11-17}$ This methodology proved to be successful in the formation of carbocyclic products from various organic halides. ${ }^{11-13}$ Olivero et al. ${ }^{13}$ have employed electrogenerated $\mathrm{Ni}(\mathrm{I})$ species to catalyse the intramolecular cyclisation of 2- haloaryl ethers containing unsaturated side chains. Over the past few years we have focused our attention on electroreductive intramolecular cyclisation using macrocyclic Ni(II) complexes in order to synthesise carbocyclic products ${ }^{17}$ and substituted tetrahydrofurans. ${ }^{18,19}$ Bromopropargyloxy substrates and cyclic products were prepared as starting materials and standard samples for GC analysis, respectively, as shown in Scheme 1.

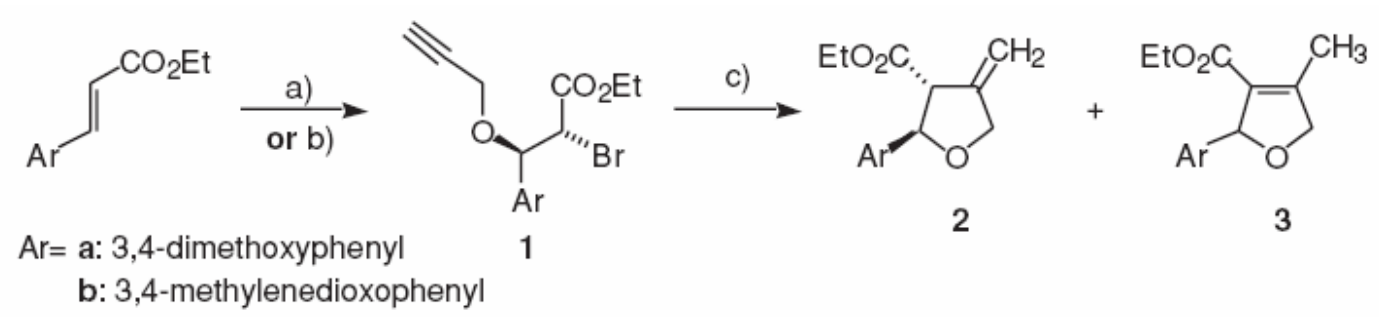

Scheme 1 Reagents and conditions: (a) N-bromosuccinimide, propargyl alcohol, $-15^{\circ} \mathrm{C} \rightarrow$ R.T.; (b) $\mathrm{LiBr}$, cerium ammonium nitrate, propargyl alcohol, N2, R.T.; (c) EPHP, AIBN, toluene, reflux.

In this paper we present a brief discussion of the stereochemical outcome of the bromoalkoxylation and cyclisation reactions based on NMR spectroscopic analysis. The bromoalkoxylation reactions were carried out by two different methods in order to improve the yields. $^{20,21}$

\section{Results and discussion}

Our chemical cyclisation reactions afforded 2 along withanother product, isomeric with 2 (a and $\mathbf{b}$ ) and identified as $\mathbf{3}$ (a and $\mathbf{b}$ ). To the best of our knowledge this is the first time that compound $\mathbf{3}$ has been obtained. The formation of 3a was corroborated by our studies on 
electroreductive intramolecular cyclisation. Indeed, this compound was one of the two major products recovered from the electrolysis medium. ${ }^{19}$

Based on Baldwin's rules ${ }^{22}$ it might be predicted that compound 2 would be the only cyclic substrate formed. The radical obtained from $\mathbf{1}$ by abstraction of Br ${ }^{\bullet}$ cyclises preferentially in a 5-exo-dig manner. We believe that compound $\mathbf{3}$ is formed via a base-catalysed isomerisation of $\mathbf{2}$. The proton adjacent to the carboxylic ester group in $\mathbf{2}$ is strongly acidic. If the (HPO2Br)- anion, present in the reaction medium of chemical cyclisation, acts as a base for compound 2, a stabilised carbanion is formed which can add a proton affording 3 . Moreover, it is well-established in the literature ${ }^{23}$ that unconjugated $\beta, \gamma$-unsaturated carbonyl compounds readily rearrange to their thermodynamically more stable conjugated isomers. In these base-catalysed reactions, the intermediate is a conjugated dienolate ion, which is reprotonated at the $\gamma$-carbon. We have also proposed a similar mechanism for the formation of 3 under electrochemical cyclisation conditions. ${ }^{19}$ Changing the ester group to a moderate electron-withdrawing group (phenyl), the cyclisation reaction afforded exclusively a product of type $2 .^{22}$

The cyclisation reactions afforded an excellent trans selectivity which can be properly interpreted within the stereoinduction Beckwith-Houk model. ${ }^{25}$ The cyclisation must occur by way of the resonance stabilised radical 4 (Fig. 1) in which the hydrogen atom, geminal with the aryl group, is syn to the olefinic bond of the delocalised radical.
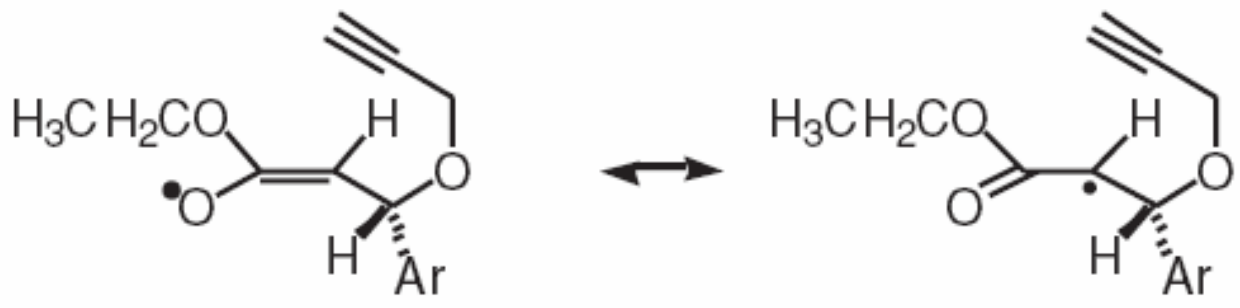

4

Fig. 1 Resonance forms of radical 4.

This radical may be drawn in a "chair-like" conformation 5a and 5b (Fig. 2) although the reaction occurred by form $\mathbf{5 a}$. 


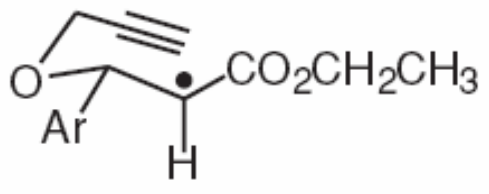

$5 a$

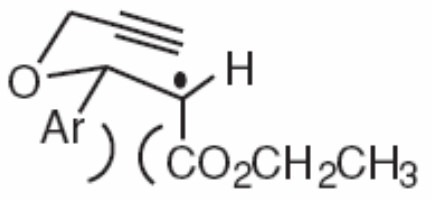

$5 b$

Fig. 2 Conformations of radical 4.

The trans-configuration is confirmed by the ${ }^{1} \mathrm{H}$ NMR data for compounds $\mathbf{2 a}$ and $\mathbf{2} \mathbf{b}$. In fact, the coupling constants between 2-H and 3-H are about $9 \mathrm{~Hz}$. Based on the Karplus equation this value for coupling constant between two vicinal protons is associated with a torsion angle approximately $180^{\circ}$. The value of $J_{\mathrm{H} 2 \mathrm{H} 3}$ analysed by this equation leads to na estimated $\mathrm{H} 2-\mathrm{C} 2-\mathrm{C} 3-\mathrm{H} 3$ dihedral angle of $166.5^{\circ}$. The molecular conformation proposed for these compounds, as well as for bromoalkoxylated substrates of type 1, was corroborated through a geometry optimisation by molecular mechanics calculations using the Hyperchem 7.0 molecular modeling software. In fact, the values calculated by this approach were $158^{\circ}$ and $167^{\circ}$ for $\mathbf{2 a}$ and $\mathbf{2 b}$, respectively. The corresponding torsion angles for $1 \mathbf{a}$ and $\mathbf{1 b}$ were found to be $178^{\circ}$ and $179^{\circ}$, respectively.

The ${ }^{1} \mathrm{H}$ NMR spectrum of compound 1a was run in $\mathrm{CDCl}_{3}$ and $\mathrm{C}_{6} \mathrm{D}_{6}$ to clarify some coupling patterns. In fact, the signal centred at $4.29 \mathrm{ppm}$ was better resolved in $\mathrm{C}_{6} \mathrm{D}_{6}$, showing 12 lines and coupling constants of 7.2 and $10.8 \mathrm{~Hz}$. The signal at $4.00 \mathrm{ppm}$ was well defined appearing as a doublet of $\mathrm{AB}$ quartets with coupling constants of 2.4 and 15.6 $\mathrm{Hz}$.

The ${ }^{1} \mathrm{H}$ NMR spectra for all compounds show some complexity of the signals due to direct and long-range couplings. Complete assignment of proton and carbon spectra was achieved by double resonance, DEPT, HMQC and HMBC techniques. None of the spectra of these compounds shows evidence of mixtures of isomers as was inferred by the appearance of only one set of signals in the ${ }^{1} \mathrm{H}$ NMR spectrum. For all compounds a common splitting pattern for the ester methylene protons was found and described as a quartet of $\mathrm{AB}$ quartets (although partially superimposed) with coupling constants of about 7 and $11 \mathrm{~Hz}$. In our opinion the complex signal observed for the ester methylene protons of $\mathbf{1 a}-\mathbf{b}$ could not be attributed to a mixture of threo and erythro isomers as reported in the literature. ${ }^{20} \mathrm{We}$ 
believe that only the more stable threo isomer was formed as a racemic mixture. For compounds 1a and $\mathbf{1 b}$ the two methylene protons next to the triple bond are diastereotopic and are coupled to each other and also with the methyne proton. The signal in the ${ }^{1} \mathrm{H}$ NMR spectrum is in fact a doublet of AB quartets $(J 2.4$ and $15.6 \mathrm{~Hz})$. This splitting could not be attributed to a 1:1 mixture of threo and erythro isomers as was claimed by Roy et al. ${ }^{26}$ The data obtained from ${ }^{1} \mathrm{H}$ and ${ }^{13} \mathrm{C}$ spectra do not show duplication of any other peaks which excludes the presence of a mixture of isomers.

In conclusion, the bromoalkoxylation reaction, as well as the formation of compounds 2 , were stereoselective affording the more stable threo isomers as shown by nuclear magnetic resonance data. Furthermore, cyclisation reactions afforded na unexpected product which was obtained in the cyclisation reactions.

\section{Experimental}

All melting points were measured on a Gallenkamp apparatus and are uncorrected. NMR spectra were run at $25{ }^{\circ} \mathrm{C}$. ${ }^{1} \mathrm{H}$ NMR spectra were recorded at $300 \mathrm{MHz}$ and ${ }^{13} \mathrm{C}$ NMR spectra were determined at 75.4 MHz on a Varian Unity Plus Spectrometer. In the NMR spectra was used the solvent peak as internal reference. Elemental analyses were obtained on a Leco CHNS-932. Column chromatography was performed on silica gel (230-400 mesh) under conditions that are described below. Light petroleum refers to the fraction boiling in the range $40-60{ }^{\circ} \mathrm{C}$.

\section{Experimental procedure for bromoalkoxylation reactions}

Method $A^{20}$ : A solution $(0.30-0.40 \mathrm{M})$ of alkene (commercial) in dry dichloromethane was added dropwise to another solution of recrystallised $N$-bromosuccinimide (1.5 equiv.) in propargyl alcohol (5 equiv.) at $-15^{\circ} \mathrm{C}$ (salt-ice bath). The resulting mixture was stirred at this temperature for two hours followed by $24 \mathrm{~h}$ at room temperature. The reaction mixture was diluted with dichloromethane and successively washed with $1 \%$ aqueous sodium metabissulfite, $5 \%$ aqueous sodium thiosulfate, water and dried $\left(\mathrm{MgSO}_{4}\right)$. The residue was purified by flash chromatography using ethyl acetate-light petroleum 2:1 (for 1a) or dichloromethane-diethyl ether-light petroleum 1:1:4 (for 1b) as eluant. Recrystallisation from methanol afforded the pure 1a in $36 \%$ yield, m.p. $79-80^{\circ} \mathrm{C}$. Compound $\mathbf{1 b}$ was isolated as an oil in $20 \%$ yield. 
Method $B^{21}$ : To a solution of alkene $(1 \mathrm{mmol})$ in dry acetonitrile $(5 \mathrm{ml})$ under nitrogen it was successively added dry lithium bromide (2 equiv.), propargyl alcohol (12.4 equiv.) and a solution of cerium ammonium nitrate (1.8 equiv.) in dry acetonitrile $(5 \mathrm{ml})$ at room temperature. The resulting mixture was stirred under nitrogen for $24 \mathrm{~h}$. Then it was diluted with diethyl ether and washed with saturated sodium bicarbonate, water, brine, water and dried $\left(\mathrm{MgSO}_{4}\right)$. The residue was purified by recrystallisation from $\mathrm{MeOH}$ (for 1a) or by flash cromatography (ethyl acetate-light petroleum 1:4) (for $\mathbf{1 b}$ ). The yields obtained were 70 (1a) and $57 \%(\mathbf{1 b})$; m.p. $80-81.5^{\circ} \mathrm{C}$ for $1 \mathbf{a}$.

Ethyl 2-bromo-3-(3', 4'-dimethoxyphenyl)-3-(propargyloxy) propanoate (1a): $\delta_{\mathrm{H}}\left(\mathrm{CDCl}_{3}\right) 1.33\left(3 \mathrm{H}, \mathrm{t} J 7.2 \mathrm{~Hz}, \mathrm{OCH}_{2} \mathrm{CH}_{3}\right), 2.43\left(1 \mathrm{H}, \mathrm{t} J 2.4 \mathrm{~Hz}, \mathrm{OCH}_{2} \mathrm{C} \alpha \mathrm{CH}\right), 3.88(6 \mathrm{H}$, s, $\left.2 \mathrm{xOCH}_{3}\right), 4.00\left(2 \mathrm{H}, \mathrm{dABq} J 2.4\right.$ and $\left.15.6 \mathrm{~Hz}, \mathrm{OCH}_{2} \mathrm{CaCH}\right), 4.24(1 \mathrm{H}, \mathrm{d} J 10.0 \mathrm{~Hz}, 3-\mathrm{H})$, $4.29\left(2 \mathrm{H}, \mathrm{qABq} J 7.2\right.$ and $\left.10.8 \mathrm{~Hz}, \mathrm{OCH}_{2} \mathrm{CH}_{3}\right), 4.93(1 \mathrm{H}, \mathrm{d} J 10.0 \mathrm{~Hz}, 2-\mathrm{H}), 6.85(1 \mathrm{H}, \mathrm{d} J$ $\left.8.4 \mathrm{~Hz}, 5^{\prime}-H\right), 6.88\left(1 \mathrm{H}, \mathrm{d} J 1.8 \mathrm{~Hz}, 2^{\prime}-H\right), 6.94\left(1 \mathrm{H}, \mathrm{dd} J 8.4\right.$ and $\left.1.8 \mathrm{~Hz}, 6^{\prime}-H\right) . \delta_{\mathrm{C}}\left(\mathrm{CDCl}_{3}\right)$ $13.88\left(\mathrm{OCH}_{2} \mathrm{CH}_{3}\right), 47.48(\mathrm{C}-3) ; 55.73$ and $55.82\left(2 \mathrm{xOCH}_{3}\right), 56.16\left(\mathrm{OCH}_{2} \mathrm{C} \equiv \mathrm{CH}\right), 62.05$ $\left(\mathrm{OCH}_{2} \mathrm{CH}_{3}\right), 74.93\left(\mathrm{OCH}_{2} \mathrm{C} \equiv \mathrm{CH}\right), 78.58\left(\mathrm{OCH}_{2} \mathrm{C} \equiv \mathrm{CH}\right), 80.73(\mathrm{C}-2), 109.91\left(\mathrm{C}-2^{\prime}\right), 110.44$ (C-5'), 121.48 (C-6'), 128.09 (C-1'), $149.03\left(\mathrm{C}^{\prime} 4^{\prime}\right)$ or (C-3') and 149.51 (C-3') or (C-4'), $168.44(\mathrm{C}=\mathrm{O})$.

Ethyl 2-bromo-3-(3', 4'-methylenedioxophenyl)-3-(propargyl oxy) propanoate (1b): $\delta_{\mathrm{H}}\left(\mathrm{CDCl}_{3}\right) 1.35\left(3 \mathrm{H}, \mathrm{t} J 7.0 \mathrm{~Hz}, \mathrm{OCH}_{2} \mathrm{CH}_{3}\right), 2.44\left(1 \mathrm{H}, \mathrm{t} J 2.4 \mathrm{~Hz}, \mathrm{OCH}_{2} \mathrm{C} \alpha \mathrm{CH}\right), 4.00(2 \mathrm{H}$, dABq $J 2.4$ and $\left.15.6 \mathrm{~Hz}, \mathrm{OCH}_{2} \mathrm{CaCH}\right), 4.21(1 \mathrm{H}, \mathrm{d} J 10.2 \mathrm{~Hz}, 3-H), 4.31$ (2H, qABq $J 7.0$ and $\left.11.0 \mathrm{~Hz}, \mathrm{OCH}_{2} \mathrm{CH}_{3}\right), 4.87(1 \mathrm{H}, \mathrm{d} J 10.2 \mathrm{~Hz}, 2-\mathrm{H}), 6.01\left(2 \mathrm{H}, \mathrm{s}, \mathrm{OCH}_{2} \mathrm{O}\right), 6.82(1 \mathrm{H}, \mathrm{d} J$ $8.4 \mathrm{~Hz}, 5 '-H), 6.86-6.90\left(2 \mathrm{H}, \mathrm{m}, 2^{\prime}-\mathrm{H}\right.$ and 6'- $\left.-\mathrm{H}\right) . \delta_{\mathrm{C}}\left(\mathrm{CDCl}_{3}\right) 13.89\left(\mathrm{OCH}_{2} \mathrm{CH}_{3}\right), 47.40(\mathrm{C}-3)$, $56.14\left(\mathrm{OCH}_{2} \mathrm{C \alpha CH}\right), 62.06\left(\mathrm{OCH}_{2} \mathrm{CH}_{3}\right), 75.04\left(\mathrm{OCH}_{2} \mathrm{C \alpha CH}\right), 78.50\left(\mathrm{OCH}_{2} \mathrm{C \alpha CH}\right), 80.56$ (C-2), 101.24 (OCH2O), 107.56 (C-2'), 107.94 (C-5'), 122.69 (C-6'), 129.63 (C-1'), 147.92 $\left(\mathrm{C}-4^{\prime}\right)$ or $\left(\mathrm{C}-3^{\prime}\right)$ and $148.23\left(\mathrm{C}-3^{\prime}\right)$ or $\left(\mathrm{C}-4^{\prime}\right), 168.36(\mathrm{C}=\mathrm{O})$.

Experimental procedure for intramolecular cyclisation reactions ${ }^{9,19}$

To a stirred solution of the bromoalkoxylated substrates $(\mathbf{1 a}, \mathbf{1 b} ; 1 \mathrm{mmol})$ in toluene $(0.066$ M), EPHP (5 equiv.) and AIBN (0.2 equiv.) were added. The resulting mixture was refluxed for $4 \mathrm{~h}$ and concentrated. The residue was taken up in dichloromethane and the solution obtained was filtered over a pad of Celite, washed with brine and water. Dried $\left(\mathrm{MgSO}_{4}\right)$ organic phase was concentrated and purified by flash chromatography using 
dichloromethane-diethyl ether-light petroleum 1:1:1 (for 2a and 3a) or diethyl ether-light petroleum 1:2 (for $\mathbf{2} \mathbf{b}$ and $\mathbf{3 b}$ ). In both cases the first eluted material was identified as $\mathbf{2 a}$ or $\mathbf{2} \mathbf{b}$ and the second eluted material as $\mathbf{3} \mathbf{a}$ or $\mathbf{3} \mathbf{b}$. Compounds $\mathbf{2} \mathbf{a}-\mathbf{b}$ and $\mathbf{3 a}-\mathbf{b}$ were obtained as light yellow oils, in yields (\%) as follows: 2a: 40; 2b: 37; 3a: 25; 3b: 30.

2-(3',4'-dimethoxyphenyl)-3-(ethoxycarbonyl)-4-methylene tetrahydrofuran (2a):

$\delta_{\mathrm{H}}\left(\mathrm{CDCl}_{3}\right) 1.28\left(3 \mathrm{H}, \mathrm{t} J 7.2 \mathrm{~Hz}, \mathrm{OCH}_{2} \mathrm{CH}_{3}\right), 3.49(1 \mathrm{H}$, apparent ddd $J$ 8.7, 2.4 and $2.4 \mathrm{~Hz}$, 3- $\mathrm{H}), 3.88\left(3 \mathrm{H}, \mathrm{s}, \mathrm{OCH}_{3}\right), 3.90\left(3 \mathrm{H}, \mathrm{s}, \mathrm{OCH}_{3}\right), 4.22(2 \mathrm{H}, \mathrm{qABq} J 7.2$ and $11.0 \mathrm{~Hz}$, $\left.\mathrm{OCH}_{2} \mathrm{CH}_{3}\right), 4.50(1 \mathrm{H}$, apparent dq $J 13.2$ and $2.4 \mathrm{~Hz}, 5-H), 4.65(1 \mathrm{H}$, br apparent d $J 13.2$ $\mathrm{Hz}, 5-H), 5.11(1 \mathrm{H}$, apparent q J $2.4 \mathrm{~Hz}, \mathrm{C}=\mathrm{CH}), 5.19(1 \mathrm{H}, \mathrm{d} J 8.7 \mathrm{~Hz}, 2-H), 5.20(1 \mathrm{H}$, apparent q J $2.4 \mathrm{~Hz}, \mathrm{C}=\mathrm{CHH}), 6.84\left(1 \mathrm{H}, \mathrm{d} J 8.7 \mathrm{~Hz}, 5^{\prime}-H\right), 6.90\left(1 \mathrm{H}, \mathrm{d} J 1.8 \mathrm{~Hz}, 2^{\prime}-H\right), 6.91$ $\left(1 \mathrm{H}\right.$, dd $J 8.7$ and $\left.1.8 \mathrm{~Hz}, 6{ }^{\prime}-H\right) . \delta_{\mathrm{C}}\left(\mathrm{CDCl}_{3}\right) 14.11\left(\mathrm{OCH}_{2} \mathrm{CH}_{3}\right), 55.70\left(\mathrm{OCH}_{3}\right), 55.74$ $\left(\mathrm{OCH}_{3}\right), 56.94(\mathrm{C}-3), 61.00\left(\mathrm{OCH}_{2} \mathrm{CH}_{3}\right), 71.36(\mathrm{C}-5), 83.23(\mathrm{C}-2), 106.14\left(\mathrm{C}=\mathrm{CH}_{2}\right), 108.86$ (C-2'), 110.76 (C-5'), 118.48 (C-6'), 132.15 (C-1'), 146.44 (C-4), 148.71 (C-3') and (C-4'), $170.60(\mathrm{C}=\mathrm{O})$. Calc. for $\mathrm{C}_{16} \mathrm{H}_{20} \mathrm{O}_{5} \mathrm{C}, 65.73 ; \mathrm{H}, 6.91$. Found $\mathrm{C}, 65.64 ; \mathrm{H}, 6.86$.

2-(3',4'-methylenedioxophenyl)-3-(ethoxycarbonyl)-4-methylenetetrahydrofuran (2b):

$\delta_{\mathrm{H}}\left(\mathrm{CDCl}_{3}\right) 1.28\left(3 \mathrm{H}, \mathrm{t} J 7.2 \mathrm{~Hz}, \mathrm{OCH}_{2} \mathrm{CH}_{3}\right), 3.42-3.47(1 \mathrm{H}, \mathrm{m}, 3-\mathrm{H}), 4.21(2 \mathrm{H}, \mathrm{qA}$ Bq $J .2$ and $\left.11.0 \mathrm{~Hz}, \mathrm{OCH}_{2} \mathrm{CH}_{3}\right), 4.49(1 \mathrm{H}$, apparent dq $J 13.0$ and $2.4 \mathrm{~Hz}, 5-\mathrm{H}), 4.63(1 \mathrm{H}, \mathrm{br}$ apparent d $J 13.0 \mathrm{~Hz}, 5-H), 5.10(1 \mathrm{H}$, apparent q $J 2.4 \mathrm{~Hz}, \mathrm{C}=\mathrm{CHH}), 5.15(1 \mathrm{H}, \mathrm{d} J 8.7 \mathrm{~Hz}, 2-$ $H), 5.18(1 \mathrm{H}$, apparent q $J 2.4 \mathrm{~Hz}, \mathrm{C}=\mathrm{CHH}), 5.96\left(2 \mathrm{H}, \mathrm{s}, \mathrm{OCH}_{2} \mathrm{O}\right), 6.77\left(1 \mathrm{H}, \mathrm{d} J 8.0 \mathrm{~Hz}, 5^{\prime}-\right.$ $H), 6.88\left(1 \mathrm{H}\right.$, dd $J 8.0$ and $\left.1.8 \mathrm{~Hz}, 6^{\prime}-H\right), 6.90\left(1 \mathrm{H}, \mathrm{d} J 1.8 \mathrm{~Hz}, 2^{\prime}-H\right) . \delta_{\mathrm{C}}\left(\mathrm{CDCl}_{3}\right) 14.17$ $\left(\mathrm{OCH}_{2} \mathrm{CH}_{3}\right), 57.12(\mathrm{C}-3), 61.12\left(\mathrm{OCH}_{2} \mathrm{CH}_{3}\right), 71.44(\mathrm{C}-5), 83.28(\mathrm{C}-2), 101.01\left(\mathrm{OCH}_{2} \mathrm{O}\right)$, $106.31\left(\mathrm{C}=\mathrm{CH}_{2}\right), 106.51\left(\mathrm{C}-2^{\prime}\right), 108.10\left(\mathrm{C}-5^{\prime}\right), 119.76\left(\mathrm{C}-6{ }^{\prime}\right), 133.69\left(\mathrm{C}-1^{\prime}\right), 146.36(\mathrm{C}-4)$, $147.37\left(\mathrm{C}-4^{\prime}\right)$ or $\left(\mathrm{C}^{-3}\right)$ and $147.79\left(\mathrm{C}-3^{\prime}\right)$ or $\left(\mathrm{C}-4^{\prime}\right), 170.60(\mathrm{C}=\mathrm{O})$. Calc. For $\mathrm{C}_{15} \mathrm{H}_{16} \mathrm{O}_{5} \mathrm{C}$, 65.20; H, 5.85. Found C, 65.05; H, 5.69.

2-(3', 4'-dimethoxyphenyl)-3-(ethoxycarbonyl)-4-methyl-2,5-dihydrofuran (3a):

$\delta_{\mathrm{H}}\left(\mathrm{CDCl}_{3}\right) 1.15\left(3 \mathrm{H}, \mathrm{t} J 7.0 \mathrm{~Hz}, \mathrm{OCH}_{2} \mathrm{CH}_{3}\right), 2.19\left(3 \mathrm{H}\right.$, apparent d $\left.J 1.2 \mathrm{~Hz}, 4-\mathrm{CH}_{3}\right), 3.87$ $\left(3 \mathrm{H}, \mathrm{s}, \mathrm{OCH}_{3}\right), 3.88\left(3 \mathrm{H}, \mathrm{s}, \mathrm{OCH}_{3}\right), 4.08\left(2 \mathrm{H}, \mathrm{qABq} J 7.0\right.$ and $\left.11.0 \mathrm{~Hz}, \mathrm{OCH}_{2} \mathrm{CH}_{3}\right), 4.72$ $(1 \mathrm{H}$, apparent ddd $J 15.0,3.6$ and $1.2 \mathrm{~Hz}, 5-H), 4.89(1 \mathrm{H}$, apparent ddd $J 15.0,5.7$ and 0.9 $\mathrm{Hz}, 5-H), 5.88-5.92(1 \mathrm{H}, \mathrm{m}, 2-H), 6.83\left(1 \mathrm{H}, \mathrm{d} J 8.1 \mathrm{~Hz}, 5^{\prime}-H\right), 6.84(1 \mathrm{H}$, br s, 2'-H), 6.88 $\left(1 \mathrm{H}\right.$, dd $J 8.1$ and $\left.1.8 \mathrm{~Hz}, 6{ }^{\prime}-\mathrm{H}\right) . \delta_{\mathrm{C}}\left(\mathrm{CDCl}_{3}\right) 11.95\left(4-\mathrm{CH}_{3}\right), 13.99\left(\mathrm{OCH}_{2} \mathrm{CH}_{3}\right), 55.77$ $\left(\mathrm{OCH}_{3}\right), 55.81\left(\mathrm{OCH}_{3}\right), 60.01\left(\mathrm{OCH}_{2} \mathrm{CH}_{3}\right), 79.35(\mathrm{C}-5), 88.66(\mathrm{C}-2), 110.30(\mathrm{C}-5), 110.73$ 
(C-2'), 119.57 (C-6'), 127.12 (C-4), 134.09 (C-1'), 148.69 (C-3') or (C-4') and 148.73 (C-4') or (C-3'), $150.41(\mathrm{C}-3), 163.39(\mathrm{C}=\mathrm{O})$. Calc. for $\mathrm{C}_{16} \mathrm{H}_{20} \mathrm{O}_{5} \mathrm{C}, 65.73 ; \mathrm{H}, 6.91$. Found $\mathrm{C}$, $65.50 ; \mathrm{H}, 6.75$.

2-(3',4'-methylenedioxophenyl)-3-(ethoxycarbonyl)-4-methyl-2,5-dihydrofuran(3b):

$\delta_{\mathrm{H}}\left(\mathrm{CDCl}_{3}\right) 1.16\left(3 \mathrm{H}, \mathrm{t} J 7.2 \mathrm{~Hz}, \mathrm{OCH}_{2} \mathrm{CH}_{3}\right), 2.18\left(3 \mathrm{H}\right.$, apparent d J $\left.1.2 \mathrm{~Hz}, 4-\mathrm{CH}_{3}\right), 4.09$ $\left(2 \mathrm{H}, \mathrm{qABq} J 7.2\right.$ and $\left.10.8 \mathrm{~Hz}, \mathrm{OCH}_{2} \mathrm{CH}_{3}\right), 4.71(1 \mathrm{H}$, apparent ddd $J 15.0,3.5$ and $1.0 \mathrm{~Hz}, 5-$ $H), 4.87(1 \mathrm{H}$, apparent ddd $J 15.0,5.0$ and $1.0 \mathrm{~Hz}, 5-H), 5.83-5.87(1 \mathrm{H}, \mathrm{m}, 2-H), 5.94(2 \mathrm{H}$, s, $\left.\mathrm{OCH}_{2} \mathrm{O}\right), 6.76\left(1 \mathrm{H}, \mathrm{d} J 8.0 \mathrm{~Hz}, 5^{\prime}-\mathrm{H}\right), 6.77\left(1 \mathrm{H}, \mathrm{d} J 1.8 \mathrm{~Hz}, 2^{\prime}-H\right), 6.82(1 \mathrm{H}$, dd $J 8.0$ and $1.8 \mathrm{~Hz}, 6$ '-H). $\delta_{\mathrm{C}}\left(\mathrm{CDCl}_{3}\right) 11.92\left(4-\mathrm{CH}_{3}\right), 13.99\left(\mathrm{OCH}_{2} \mathrm{CH}_{3}\right), 60.03\left(\mathrm{OCH}_{2} \mathrm{CH}_{3}\right), 79.41(\mathrm{C}-$ 5), 88.66 (C-2), $100.95\left(\mathrm{OCH}_{2} \mathrm{O}\right), 107.39$ (C-2'), 107.88 (C-5'), 121.00 (C-6'), 127.06 (C-4), $135.59\left(\mathrm{C}-1^{\prime}\right), 147.28\left(\mathrm{C}-4^{\prime}\right)$ or (C-3') and $147.56\left(\mathrm{C}-3^{\prime}\right)$ or (C-4'), $150.33(\mathrm{C}-3), 163.26$ $(\mathrm{C}=\mathrm{O})$. Calc. For $\mathrm{C}_{15} \mathrm{H}_{16} \mathrm{O}_{5} \mathrm{C}, 65.20 ; \mathrm{H}, 5.85$. Found $\mathrm{C}, 65.10 ; \mathrm{H}, 5.70$.

The authors gratefully acknowledge the financial support from FEDER and Fundação para a Ciência e Tecnologia (POCTI/QUI/37808/2001).

\section{References}

1 T.Y. Simpson, In The Chemistry of Natural Products, R.H. Thomson, Ed.; Blackie: Glasgow, 1985. pp 123-125.

2 B. Giese, Radicals in Organic Synthesis: Formation of carbon-carbon bonds; Pergamon Press; Oxford, 1986.

3 A.L. Beckwith, J. Chem. Soc. Rev., 1993, 143.

4 B. Venugopalan, P.J. Karnik, S. Shinde, J. Chem. Soc., Perkin Trans. 1, 1996, 1015.

5 G. Stork, R. Mook Jr, J. Am. Chem. Soc., 1983, 105, 3720.

6 W.R. Dolbier Jr., X.X. Rong, B.E. Smart, Z.Y. Yang, J. Org. Chem., 1996, 61, 4824.

7 J. Quirante, C. Escolano, A. Merino, J. Bonjoch, J. Org. Chem., 1998, 63, 968.

8 J.M.B. Calderon, G.J. Chicharro, R.J. Fiandorn, S. Huss, RA. Ward EP 96-500056.

9 R. McCague, R.G. Pritchard, R.J. Stoodley, D. Williamson, Chem. Commun., 1998, 2691. 
10 S.R. Graham, J.A. Murphy, D. Coates, Tetrahedron Lett., 1999, 40, 2415.

11 S. Ozaki, E. Matsui, J. Waku, H. Ohmori, Tetrahedron Lett., 1997, 38, 2705.

12 M. Ihara, A. Katsumata, F. Setsu, Y. Tokunaga, K. Fukumoto, J. Org. Chem., 1996, 61, 677.

13 S. Olivero, J.P. Rolland, E. Duñach, Organometallics, 1998, 17, 3747.

14 M.S. Mubarak, D. Peters, J. Electroanal. Chem., 1992, 332, 127.

15 D.M. Fang, D.J. Peters, M.S. Mubarak, J. Electrochem. Soc., 2001, 148, E 464-E.

16 A.P. Esteves, A.M. Freitas, M.J. Medeiros, D. Pletcher, J. Electroanal. Chem., 2001, 499, 95.

17 E. Duñach, A.P. Esteves, A.M. Freitas, M.A. Lemos, M.J. Medeiros, S. Olivero, Tetrahedron Lett., 1999, 40, 8693.

18 E. Duñach, A.P. Esteves, A.M. Freitas, M.A. Lemos, M.J. Medeiros, S. Olivero, S. Pure Appl. Chem., 2001, 73, 1941.

19 A.P. Esteves, D.M. Goken, L.J. Klein, M.A. Lemos, M.J. Medeiros, D.G. Peters, J. Org. Chem., 2003, 68, 1024.

20 S.C. Roy, S. Adhikari, Tetrahedron, 1993, 49, 8415.

21 S.C. Roy, C. Guin, K.K. Rana, G. Maiti, Synlett, 2001, 226.

22 J.E. Baldwin,. J. Chem. Soc., Chem. Commun., 1976, 734.

23 K.P.C. Vollhardt, N.E. Schore, Organic Chemistry, 2nd ed.; W. H. Freeman \& Co: N. Y., 1994; 675.

24 A.P. Esteves, Unpublished results

25 D.P. Curran, N.A. Porter, B. Giese, Stereochemistry of Radical Reactions; VCH: Weinheim, 1996, 31.

26 S.C. Roy, C. Guin, K.K. Rana, G. Maiti, Tetrahedron, 2002, 58, 2435. 